\title{
The East Timorese in Australia: multilingual repertoires, language attitudes, practices and identity in the diaspora
}

\author{
This article explores language repertoires, attitudes, and practices amongst \\ members of the East Timorese diaspora in Australia. It relies on quantitative and \\ qualitative data gathered through a recent sociolinguistic survey, ethnographic \\ observation, as well as on general observations of online language use. Our study \\ reveals a complex and variable multilingualism that reflects in the first instance \\ specific sociolinguistic conditions and changing language policies in East Timor, \\ leading to a reshaping of language repertoires over generations in that country. \\ Participants, mostly raised in East Timor, are more multilingual than their \\ parents, but their children raised in Australia show signs of shift to English, as \\ well as evidence of reduced multilingualism. An increasing emphasis on English \\ is coupled with a rise in the importance assigned, more generally, to Tetum \\ amongst most East Timorese at the expense of Portuguese and other languages. \\ Tetum is most strongly linked to East Timorese identity whilst Portuguese and \\ other languages show signs of restricted use and status, if not decline, in the \\ Australian context. At the same time, the Hakka Chinese sub-group of East \\ Timorese maintain in Australia, as in East Timor, a different linguistic patterning \\ coupled with a strong sense of their own ethnic and linguistic identity.
}

Keywords: East Timor, multilingualism, diaspora, Tetum, Australia

\section{Introduction}

Australia has a long tradition of sociolinguistic studies on immigrant communities and their languages (e.g. Clyne and Kipp 2006; Hlavac, 2012, 2015; Musgrave and Hajek 2013; Rubino 2014; Pauwels 2016). Issues of language maintenance and shift, and multilingual language practices have been widely investigated. The present article focuses upon the East Timorese immigrant and refugee community in Australia. The subject of a number of sociological and anthropological studies (e.g. Wise 2004, 2006; Askland 2007, 2014; Costa-Pinto 2012), the East 
Timorese Australian experience has not yet been investigated from a sociolinguistic perspective. The East Timorese in Australia are of particular interest to sociolinguists because of: (a) the unusually complex linguistic situation in East Timor; (b) the complicated nature of their arrival in Australia; and (c) the ongoing close relationship the Timorese in the diaspora have always maintained with East Timor. In this context, our goal therefore is to give an account of East Timorese multilingualism in Australia and in so doing, fill a gap in the research literature about the East Timorese in the diaspora, with an eye also to better understanding of how the linguistic behaviours of immigrant communities may be conditioned and formed. Our primary research questions are the following:

(a) What are the language repertoires of the East Timorese in Australia?

(b) To what extent are these repertoires influenced by language-related experiences in East Timor - in addition to time spent in Australia?

(c) What are the language attitudes, practices and identities of the East Timorese in Australia?

One element of particular interest to us, albeit not the only one, is the relationship between a sequence of markedly different language policies in East Timor and their potential impact on language knowledge, practices and identity on the East Timorese in Australia.

This article is organised as follows. First, we present relevant background on language policy and diversity in East Timor. We then outline East Timorese movement to the diaspora as well as East Timorese multilingualism in it, including some previous 
research on the latter, before giving a detailed presentation of our own data collected in Australia. $^{1}$

\section{Language diversity and policy in East Timor}

East Timor has always been linguistically diverse - with at least 19 additional local Austronesian and non-Austronesian languages traditionally spoken in the small country (Hajek 2000, 2002). ${ }^{2}$ The country also has a complex colonial and post-colonial history that has resulted in three very different language policy settings over time.

Portuguese was introduced in East Timor when the territory became part of the Portuguese colonial empire in the 1500s. In 1955, East Timor became an 'overseas province' of Portugal, but only the so-called assimilados (assimilated natives), which represented a mere $0.25 \%$ of the pre-1976 East Timorese population, had acquired high levels of proficiency in Portuguese through education and could speak it fluently (Goglia and Afonso 2012). Given the low number of Portuguese speakers, traditional localized multilingualism involving small local languages in geographical proximity, as well as the use of Tetum (or Tetun) by many East Timorese as a more general lingua franca was not disrupted. Only in the 1960s and 1970s were significant efforts made by colonial authorities to expand the education system and expose school age children to Portuguese, the exclusive medium of instruction and of officialdom until 1975.

During the period of Indonesian occupation (1975-1999), Indonesian was imposed as the sole official language, and large numbers of Indonesian-born native speakers from Indonesia were settled in East Timor. Portuguese was banned from

\footnotetext{
${ }^{1}$ The authors wish to thank the editor and two anonymous reviewers for their kind assistance and feedback. All errors of course remain our own.

${ }^{2}$ Technically under the constitution they are identified as 'national languages' but for convenience here they will be referred to as 'local languages' and do not include Tetum which has explicit co-official status.
} 
schools, and public use while native Timorese languages were ignored, with the partial exception of Tetum, in an effort to rapidly assimilate East Timor into Indonesia.

In a conscious effort to counter Portuguese, Indonesian authorities allowed the local Catholic Church to adopt Tetum for official religious purposes with the expectation that this choice would rapidly lead to a shift to Indonesian (Hajek 2000). This particular policy decision, however, only facilitated the spread, and strengthened the status, of Tetum. with Church and Tetum becoming interlinked symbols of East Timorese identity and resistance to 'Indonesianisation'. This rise of Tetum since the 1970s, and especially since the 1990s, has also begun to impact on the traditional patterns of local language knowledge and of the localized multilingualism noted above. Today there are also clear signs of rapid shift to Tetum as the preferred language of the home (Williams-Van Klinken and Williams 2015).

Portuguese, in tandem with Tetum, survived as part of the resistance movement against Indonesian rule. The armed resistance in East Timor as well as the political resistance in the diaspora, including Australia, were led by Portuguese-speaking Timorese, and, Portuguese remained the language of official communication and of the highest status.

On independence in 2002, East Timor made Portuguese and Tetum co-official languages under its new constitution, while Indonesian and English were kept as temporary working languages within the bureaucracy. Since 2002, Indonesian has been removed systematically from schools and officialdom. In the last 15 years, the government has made significant effort to reintroduce Portuguese in education and the public sphere, and to standardize Tetum and to use it in primary education and the media. In practice, however, Portuguese is little used in daily life in which Tetum dominates. 


\section{A brief overview of East Timorese migration to the diaspora since 1975}

The migration history of East Timorese communities in the diaspora are chronologically complex (see Goglia and Afonso 2012 for a detailed presentation). In 1975 and 1976 small communities of East Timorese already living in Portugal and Australia were joined by an influx of refugees fleeing a brief civil war but especially the Indonesian invasion and occupation of what was then still known as Portuguese Timor in late 1975. There were subsequent waves of refugees in the 1980s and again in the 1990s as a result of ongoing conflict and oppression in East Timor. These refugees (especially of part of the 1980s wave) in the first instance typically travelled first to Portugal. Although some stayed there, a sizable proportion then travelled to and settled permanently in Australia through family reunion programs. As a result of the violent chaos that followed the independence referendum held in East Timor 1999, Australia accepted a new wave of East Timorese refugees but only on a temporary basis: they were quickly repatriated once the United Nations took control of East Timor. Since East Timor achieved formal independence in 2002, arrivals from that nation are generally students, and temporary visitors. Since all East Timorese born before 2002 are entitled to Portuguese citizenship, many younger Timorese have moved to Portugal to study and work. However, difficult economic conditions in Portugal have led to a noticeable process of work-related chain migration to the United Kingdom, particularly since 2002.

\section{The study of East Timorese multilingualism in the diaspora}

There are numerous studies on different aspects of multilingualism and language issues in East Timor (e.g. Hajek 2000, 2002; Taylor-Leech 2009, 2012, 2013; Boon and Kurvers 2015; Williams-van Klinken and Hajek 2018). Until recently however, researchers have not focused on the East Timorese and their languages in the diaspora, 
traditionally concentrated in Portugal and Australia but now also in the United Kingdom (UK). At least three recent studies on the East Timorese diaspora in Portugal and the UK, are of particular interest because of a focus specifically on language issues outside of East Timor that are most pertinent to this study.

Goglia and Afonso (2012), which provides the model for this study, investigated multilingualism and language maintenance among the East Timorese community in Porto (Portugal). The study provided a picture of complex linguistic repertoires in the diaspora, influenced by different generational experiences of language policies in East Timor. They showed that the East Timorese multilingual repertoire is reshaped in the Portuguese immigrant context, with Tetum being maintained and functioning as an East Timorese identity marker, Portuguese being identified as a prestigious language to learn, while Indonesian is still maintained to some degree in some specific domains. East Timorese local languages, however, are not passed on to the second generation.

In the UK, Zwack (2013) studied a recently settled East Timorese community, namely the Fataluku-speaking community in Oxford. The Fataluku are somewhat unusual in that Tetum was not traditionally used as a lingua franca in their part of East Timor (Hajek 2000). However, they have been quick since 1999 to adopt Tetum in order to align with other East Timorese. Zwack revealed the use of Fataluku, Tetum, Indonesian and Portuguese within private domains. Because the Fataluku are a tightknit community who maintain strong cultural ties with the homeland and a positive attitude towards Timorese languages as markers of their identity, they have relatively low incentive to acquire proficiency in English. That said, Zwack's research also reveals early signs of language shift towards English and Tetum as these languages are perceived as respectively more useful for Fataluku children in the UK and when returning to East Timor. 
Da Costa Cabral (2018) in a small ethnographic study studied language issues in two East Timorese families in Dungannon in Northern Ireland - a recent magnet for Timorese seeking employment abroad. She found parents in her study to perceive English as essential for their children, whilst Tetum (only used in the domestic domain) was secondary.

\section{The East Timorese in Australia}

The linguistic experience and complexity of the East Timorese migrant community in Australia is, as we shall see, significantly influenced by time of arrival in Australia, ethnic distinctions in East Timor as well as by the significant changes in language policy in that country.

As previously noted, the East Timorese in Australia belong to different migration waves. In 1975 and 1976 many East Timorese arrived in Australia as refugees, following a brief civil war and then the major Indonesian invasion that quickly followed. According to official data 2348 refugees travelled to Australia at that time (Costa-Pinto 2012: 282). Many of these refugees were members of the educated Portuguese-speaking elite of local Timorese or of mixed Timorese-Portuguese origin. They might also be first and second language speakers of different local Timorese languages, as are many other ethnic Timorese who arrived in the years that followed.

However, some East Timorese in Australia also belong to the ethnic Chinese Hakka-speaking community that arrived in East Timor in the $19^{\text {th }}$ century and has traditionally controlled most commercial activity in East Timor. Since the beginning, in East Timor and even today in Australia, the two communities are well distinguished and have tended to live somewhat separately. As a result, intermarriage in Australia and East Timor is relatively limited - a partial reflection of social conditions in East Timor, 
where the Chinese community was historically treated very differently by Portuguese authorities: its members were considered to be Taiwanese citizens and it had its own Mandarin-medium education system with Taiwanese curriculum (Hajek 2000). Knowledge of Tetum (and local languages in outlying areas), essential for trading, was common amongst the Chinese Timorese (albeit not all of them). However, the variety of Tetum they speak is immediately recognizable as heavily Hakka-accented.

After the initial wave (1976-1977), subsequent East Timorese refugee arrivals in Australia until the early 1990s, had arrived, as noted above, after spending some time in Portugal, and hence were Portuguese-speaking or at least had some significant contact with Portuguese language and people. With the occupation by Indonesia in 1975 and ensuing language policy changes, the younger generation became Indonesian-speaking. Since the mid 1990s, most East Timorese migrants to Australia have arrived directly (or sometimes via Indonesia), and are typically Indonesian educated and fluent in Indonesian, having spent much of their life under Indonesian rule, often with little or no proficiency in Portuguese

A very important feature of the East Timorese diaspora is the strong transnational link between immigrant communities in different countries and the motherland. Wise (2004) points out that the East Timorese diaspora, including in Australia, has been able to maintain a sense of collective identity via an intense longdistance nationalism that sustained national resistance against Indonesian occupation until it was overturned in 1999. Today the use of Internet and social networks among members of the community facilitates this link making contact and communication between East Timorese in different countries including Australia and East Timor very easy. Some East Timorese in Australia go back to East Timor quite frequently or work for non-government organisations in the country for periods of time. Those who do not 
travel are still in contact through the Internet, social media and by telephone and remain part of a transnational social context. This is true, for example, for the East Timorese women resident in Melbourne, Australia, who were interviewed by Costa-Pinto (2012, 287).

The East Timorese community settled in Australia (approx. 10,000 members) have for the most part either Australian or Portuguese citizenship, but also strongly identify as 'East Timorese' (Costa-Pinto 2012). Furthermore, in terms of language proficiency, the case of the East Timorese is very interesting since nationality does not necessarily match with linguistic proficiency in the co-official languages whether in the diaspora or even in East Timor. Only a minority of East Timorese in East Timor speak Portuguese and while most now do, not all speak Tetum. As already noted, most young East Timorese are fluent in Indonesian (especially if educated in the period 1976-1999) although this language is not official anymore. Local languages are still widely used in different regions of the country. Different generations are fluent in different languages, so there is not necessarily a one-to-one correspondence between national identity and language knowledge and use in East Timor.

\section{Data collection and methodology}

Our study is based on the use of different sources of data which are intended to complement each other. First and most critical are the results of a detailed sociolinguistic survey developed by Goglia and Afonso (2012) for use in Portugal: this was adapted to collect quantitative and qualitative data in the Australian context. The survey, which forms the primary basis of data presentation here, was designed to gather relevant sociolinguistic background information on the respondents (immigration to host country, education and job) in addition to including a series, often open-ended, of 
questions on language use, proficiency, and identity, respondents' language attitudes, and use of social networks and of media. This type of approach has also been successfully used by other scholars to investigate the sociolinguistics of other communities in Australia, e.g. Hlavac (2012, 2015). Secondly, we also rely on direct observation of the East Timorese community in the Australian context over many years. The first author is based in Melbourne, Australia, and is fluent in Tetum. His research has involved long term contact and interaction with a wide cross-section of Australia's East Timorese community, including research collaboration, language teaching, participation in public and private community events. (cf. Hajek 2016). He has also been a regular visitor to East Timor since the country was re-opened to outsiders in 2000, and is very familiar with the changes in language policy in that nation. Finally, the authors also examined East Timorese community public websites based in Australia in order to make general observations about such things as language use that might be relevant to this study. ${ }^{3}$

Members of the East Timorese community in Australia were invited to complete an anonymous sociolinguistic survey at two East Timorese community events held in Melbourne and Darwin respectively. Participants were also invited to take the survey via East Timorese community and interest pages on Facebook, or email, throughout 2014 and 2015. Participants could respond to the survey in English, Tetum or Portuguese. Twenty-nine East Timorese completed the survey. Whilst this figure is higher than achieved by Goglia and Afonso (2012) ( $\mathrm{n}=23)$, it should be noted that data collection of this kind is somewhat challenging, given the specific complexities of the East Timorese community in Australia, its noticeable physical dispersion in the outer

\footnotetext{
${ }^{3}$ Our evaluation and presentation of online language use, including in any social media activity, are generic and anonymous - in line with human ethics advice.
} 
suburbs of large Australia cities such as Melbourne, as well as a lack of established prior cultural experience of completing surveys, something not uncommon to many migrant communities more generally in Australia.

Despite our best efforts, participation in the survey by the Timorese Chinese community was small $(n=3)$ but in line with expectations based on the relative separateness of East Timor's Chinese community who have maintained much of this traditional dynamic in Australia.

Of our twenty-nine participants, sixteen have Darwin as their primary place of residence, eight Melbourne, and the rest elsewhere. They were then divided into three age groups - generally reflective of the three critical periods of East Timorese political and linguistic history, and accordingly can be expected to show differences in education, language knowledge and experiences. The youngest generation $(16-24, n=6)$ represent the generation born at or after the end of Indonesian occupation (1999), and the achievement of East Timorese independence (2002). The middle group (26-44, $\mathrm{n}=14)$ are linked most closely to the period of Indonesian occupation (1975-1999) when they were most likely educated and socialised. The oldest group $(46+, n=9)$ are linked most closely to the time of Portuguese control of East Timor (until 1975).

The majority of our participants were born in East Timor (22) with all age groups represented in our sample. Of the remaining seven, five, mostly in the youngest group, were born in Australia, with one each born in Portugal, and Portuguese-speaking Mozambique respectively, both arriving as young children in Australia. Three participants reported migrating from East Timor to Australia in 1975 at the time of the Indonesian occupation, seven respondents migrated in the 1980s while groups of six each arrived in the 1990s and 2000s respectively. Our sample therefore includes a good 
cross-section of participants representative of the older and newer migration waves, as well as of Australian-born and raised participants of Timorese descent.

\section{Language repertoires, and use}

As noted in section two, the East Timorese linguistic repertoire is typically complex, reflective of East Timor's complex linguistic and political history. The Australian setting is no exception and the East Timorese have further enriched their linguistic repertoire with English and also reshaped their language-use patterns.

Figure 1 shows first languages as reported by our respondents. Tetum as primary first language has by far the highest score (15) and is most often reported by participants born and raised in East Timor (cf. Goglia and Afonso 2012). Only five participants answered that Portuguese was their first language - two were participants in their late 20s born in Portugal and Mozambique, while the remaining three are in the oldest group, a clear indication of Portuguese assimilationism before 1975. Few $(n=3)$ named an East Timorese local language (Fataluku, Makasae and Naueti) as their first language. It is worth noting that only one participant mentions Indonesian - albeit together with Tetum as their first language. Four participants (all born in Australia) answered English - alone or in combination, while the Chinese Timorese respondents, born in Australia, all identify Hakka in some way.

\section{[INSERT FIGURE 1 HERE]}

Figure 2 summarises the answers to the question 'which of the following languages do you speak?' and provides us with an initial picture of language knowledge in the East Timorese community in Australia. English and Tetum score most highly. The former is the language of the host country, the latter the traditional Timorese lingua franca. Striking, however, is the fact the three Hakka-speaking respondents, born in Australia, do not identify Tetum in response to the question - a useful indication of the 
previously mentioned traditional division between Chinese and non-Chinese Timorese that appears to have been maintained in Australia. Indonesian and Portuguese are also present. As noted, Indonesian is the language in which the East Timorese born participants under 45 years were educated in East Timor under Indonesian rule, while Portuguese, the former colonial language, is the new co-official language in East Timor, and since 2002 is used more extensively, at least in theory, in education than Tetum. Here we also have many more East Timorese local languages mentioned as part of individual linguistic repertoires - in line with a more traditional localised language knowledge and multilingualism in East Timor.

\section{[INSERT FIGURE 2 HERE]}

Respondents were also asked to rate their relative proficiency in different languages. Figure 3 is a graphic representation of respondents' relative proficiencies in different languages. English is the only language all have some reasonable proficiency in, a reflection of its importance in Australia. Of the remaining languages, Tetum has the highest positive ratings (excellent, good, fair). Indonesian follows in terms of relative proficiency, and again this reflects the impact of Indonesian education on members of our sample, although some participants have little or no knowledge. The contrast with Portuguese is clear: while just over half have some reasonable proficiency, levels are lower overall, with positive evaluations typically only good to fair, rather than excellent - a reflection both of the age profile of the sample: the ones with greatest proficiency were older, as well as of the clear perception amongst East Timorese about the relative grammatical difficulty of Portuguese compared to Tetum and Indonesian.

\section{[INSERT FIGURE 3 HERE]}

The age range of participants is also salient in terms of reported proficiency as, not surprisingly, it matches different patterns of fluency and literacy in languages. The 
youngest group, more likely to be born and educated in Australia, reports greatest proficiency in English, the middle group grew up in East Timor during the Indonesian occupation and hence is much more likely to report being fluent in Indonesian, while the older group educated during Portuguese times is more likely to be fluent Portuguese speakers (in addition to speaking other languages). It is also worth noting that our young, Australian-born respondents report only poor (non-Chinese Timorese), or no proficiency at all in Tetum (Chinese Timorese). The first reflects typical generational shift from migrant language to English in the Australian context (Clyne and Kipp 2006), while the second reflects the limited role of Tetum amongst Chinese Timorese - for whom Hakka Chinese (and also Mandarin Chinese as the traditional language of primary literacy) are essential to group identity and intra-ethnic communication.

In terms of instruction medium in primary education (Figure 4), twelve reported Indonesian only, nine Portuguese only (all older than 40), and seven English (all in Australia). One subject reported both Indonesian and Tetum - a reflection of the fact that Tetum has long been used as an unofficial oral language of educational support in East Timorese schools when official instruction was or is at any point in time Indonesian or Portuguese. Those reporting Portuguese went to primary school in Portuguese Timor, i.e. until 1975.

\section{[INSERT FIGURE 4 HERE]}

With respect to language in secondary school, the situation is more complex, as seen in Figure 5. The greatest number of respondents reported Indonesian only, while three showed transition between Indonesian and other languages (with one respondent completing secondary education in East Timor, Portugal and Australia - a clear indication of the transnational experience of respondents). While nine respondents had completed primary school in Portuguese, only five had done the same in secondary 
school - a gap that also helps to explain previously noted lower levels of high proficiency in Portuguese.

[INSERT FIGURE 5 HERE]

\section{Language use within the family and other East Timorese}

The survey also included questions about language knowledge and practices of family members. In the first instance we were interested in understanding better the impact of Portuguese and Indonesian control of East Timor over time, across generations. While all of our respondents have more than one language in their repertoire, the same is not always the case for their parents who for the most part were or are still resident in East Timor, and, as a result of their age, are less likely to have expanded their language repertoires through access to Portuguese- and/or Indonesianmedium schooling in East Timor.

In Table 1 while we see that knowledge of Tetum has increased across the two generations, we also see the clear impact of contact with Portuguese and Indonesian schooling on our respondents when compared to their parents. Knowledge of Indonesian is practically unknown amongst parents - presumably because they were educated before 1976 or simply had no opportunity for schooling during Indonesian times. Fathers are more likely to speak Portuguese than mothers - a reflection of greater access of males to education in Portuguese times. Respondents were also asked to identify their parents' first language(s). While single languages for a parent were identified in less than a third of cases, many different combinations were also reported, always with Tetum and Portuguese respectively or together, but also often with multiple local languages, pointing to well-established interethnic mixing and local multilingualism in East Timor. 


\section{[INSERT TABLE 1 HERE]}

Within our sample cohort, there is also some evidence of differences in relative multilingualism between younger non-Timorese-born (7 in total, 5 in Australia, 1 in Portugal and 1 in Mozambique) and the mostly older Timorese-born (22 respondents): the former show an average knowledge of only 2.7 languages each, while the latter have a much higher rate of 3.7 languages. While some young respondents report knowledge of Tetum, as previously noted their self-rated proficiency is poor or otherwise absent. Their language skills in English on the other hand are excellent. These differences in quantity and quality are reflective of the well-known pressure in migrant communities to shift to the dominant official language, such as English in Australia (or, e.g. Portuguese in Portugal), coupled with a lack of access to education in Portuguese and/or in Indonesian. On the other hand, the average for young respondents was slightly elevated by the fact that two of the three young Australian-born respondents of Chinese Timorese origin also report fluency in Mandarin (albeit with lower self-reported proficiency than in Hakka) - the language of community language schooling, literacy and high status in that community in East Timor and abroad.

With respect to respondents' immediate family, patterns of language use were also collated. In the first instance we asked about partner's first language(s). For the seventeen respondents with partners, some combination involving Tetum was most common, including eight who were exclusively Tetum L1 speakers. Only two had partners whose first language was a Timorese local language, and three had L1 Englishspeaking partners. Three partners had Portuguese as L1 alone or in combination, while only two had Indonesian alongside Tetum and Portuguese.

When asked what language(s) they spoke with their partners, our respondents were split amongst those who used only one language (only English or Tetum) and 
those who used multiple languages but always in combination especially with Tetum (see Table 2). Those who only used English have partners born in Australia. In no partnerships were Portuguese or Indonesian used exclusively. Not surprisingly, by way of comparison, the declared use of Portuguese in partnerships in Portugal was higher as Portuguese is the language of the host country (Goglia and Afonso 2012).

\section{[INSERT TABLE 2 HERE]}

With respect to communication with children, summarised in Table 3, the increased presence of English in both directions is immediately noticeable, with English only more common when speaking with children, another typical feature of migration settings in Australia (Clyne and Kipp 2006). Tetum is also widely used, with little use of Portuguese or Indonesian. In only one case is a local language (Makasae) used with children - in combination with Tetum. The findings here demonstrate that in the immigration context, local East Timorese languages are not passed on to children, as also reported by Goglia and Afonso (2012) for Portugal - in what appears to be mirroring language shift towards Tetum in particular already occurring in East Timor (Williams-van Klinken and Williams 2015). In the immigration context, East Timorese families choose not to pass on the local languages because they are not perceived as useful for life in the host country, especially given the need or desire to accommodate the use of Tetum as the national lingua franca and co-official language. Similarly deliberate choices have been observed in other immigrant communities, for example the Igbo-Nigerians in Italy and the UK who choose not to teach Igbo to their children in favour of English and Italian even if the Igbo language is a strong marker of the Igbo identity (Goglia 2011, 2015). The East Timorese families' decision to not pass on the local languages to their children in Australia may also be explained by a lack of a large network that could ensure the transmission of the language to the future generation. 
This is also the case for the Chaldean and Assyrian communities in Melbourne studied by Hlavac (2012).

\section{[INSERT TABLE 3 HERE]}

Table 4 shows the use of languages with different members of the family, friends and other East Timorese. In all cases, a range of languages is used, although relative frequencies vary greatly. With the exception of friends, Tetum is clearly preferred with all identified interlocutors, but especially in the case of mother (52\%) and grandmother (49\%). Indonesian is little used, with the partial exception of friends $(17 \%)$, this latter datum a reflection of shared educational experience. We have observed directly in East Timor and Australia that it is not uncommon for East Timorese who attended school together to use the language of schooling when meeting later as friends as a sign of shared social status and experience.

Portuguese is used most commonly (25\%) with one's father - an indication of the status of Portuguese for older Timorese males who were educated in that language during Portuguese times. Some noticeable use of Portuguese, i.e. $>10 \%$, is used in all contexts surveyed, except with younger Timorese (7\%). The use of Hakka amongst our Timorese Chinese respondents, all of whom are in the youngest cohort, also shows some signs of generational shift with respect to domains: although numbers are small, it is clear it is less used with siblings and friends, especially when compared with the use of Hakka with parents.

The use of English is marked only for same generation relations, typically by our younger respondents, and when speaking to younger Timorese - another common indication of language shift in Australia (e.g., Clyne and Kipp 2006).

[INSERT TABLE 4 HERE] 


\section{Language attitudes}

In order to explore language attitudes, our survey included an open question on the respondents' favourite language with the possibility also for them to write the reasons for their answers. In their written replies fifteen respondents answered Tetum (either on its own or together with English and Portuguese), explaining it is the national language, the language they feel more comfortable when they speak and it represents their East Timorese identity (cf. Goglia and Afonso 2012: 91). Four older respondents (three of whom also listed Tetum) and a participant in the middle group identified Portuguese. This latter respondent stated that it 'brings other people who speak Portuguese closer, not just from East Timor'. Whilst the preference for Portuguese among older respondents can be explained because they were educated and acculturated in Portuguese, the other respondent's comment shows awareness of Portuguese being a world language useful for communication beyond East Timor, and is consistent with well-known efforts on the part of the East Timorese government to develop strong linguistic, cultural, economic and political links with other Portuguese-speaking nations, particularly through the mechanism of the CPLP (Comunidade dos Paises de Lingua Portuguesa 'Community of Portuguese-speaking Countries'). Nine answers included English which was often identified as an international language and the language of the host country. Only two respondents also answered with Indonesian, and without providing any reasons for their choice. Two respondents included local languages respectively: Makasae (1) and Naueti (1).

The three Hakka speakers in our sample answered only Hakka with respect to their favourite language. Their reasons for a positive attitude towards that variety of Chinese included: 'it's my ancestors' mother tongue', and in particular 'it is the sole or dominant dialect spoken by the Chinese community in East Timor which means we are 
a very close group' - a revealing comment highlighting in-group awareness of the special nature of that sub-community.

\section{Language and identity}

With respect to identity, individuals are recognised as having multiple possible identities (e.g. individual, group) each of which can be determined in different ways (Tabouret-Keller 1997). Language is a well-known marker of both individual and group identity (Coulmas 2005, Edwards 2009). National identity has long been recognised as 'perhaps the most fundamental and inclusive' type of group identity (Smith 1991:143). In the case of East Timor we have a young nation that struggled to achieve independence, so national identity is particularly relevant. But it is also one that is only recently formed (i.e. largely since 1975 and especially since independence in 2002). There is no doubt that language(s) are important markers of group identity in East Timor, figuring prominently in popular discussions - whether with respect to specific ethnic group identity (e.g. the Fataluku are Fataluku-speaking) or to national identity and language policy (see, e.g. Hajek 2000).

Group identity is also relevant in the immigration context. National identity/ national languages are often the main markers immigrant groups use to identify themselves as a different group in the foreign country where awareness of the actual internal ethnolinguistic diversity within the immigrant group typically remains unknown (cf. Musgrave and Hajek 2010 on the 'invisibility' of Sudanese languages in Australia).

In both cases (national identity in general and identity in the immigration context) the 'us and them' borders can be very strong and help to establish group allegiances (cf. Tabouret-Keller 1997). 
One survey question asked about our participants' perception of which language they speak best represents their East Timorese identity - in an effort to determine which language(s) participants wish to claim rather than have ascribed to them as part of their identity. As seen in Figure 6, our results show clearly that the overwhelming majority of participants $(n=23)$ responded with Tetum, only one respondent answered Tetum together with Portuguese and another with Makasae. Only one respondent, born in Mozambique, answered Portuguese on its own. No respondent identified Indonesian an indication that 24 years of intense Indonesianisation of East Timor have not entrenched the language amongst the Timorese, as well as a reflection of its declining general importance in East Timor itself since 1999. Again, the three respondents who identified Hakka as important for their East Timorese identity were all of Chinese descent.

\section{[INSERT FIGURE 6 HERE]}

The emphasis on Tetum as the linguistic marker of East Timorese identity is expected as the majority of participants are below 45 years of age and most are not particularly fluent in Portuguese, co-official in East Timor. Furthermore, Portuguese as an immigrant language in Australia is not particularly linked to the East Timorese but also belongs to other resident Lusophone communities such as the Brazilians and the Portuguese. It is worth noting that Goglia and Afonso (2012) also found that Tetum best represents East Timorese identity in Portugal, although their participants were all fluent in Portuguese. The authors ascribed this finding to the fact that in their case Portuguese is both the language of the host country and co-official language in East Timor, so it cannot function as a specific marker of East Timorese identity. 
In the case of East Timorese in Australia, it is critical to note that we have been able to observe through direct contact with the community a significant shift in attitude since the early 1990s away from Portuguese towards Tetum as the main linguistic marker of East Timorese identity. During the struggle against Indonesian occupation (1975-1999), Portuguese was consistently identified by the anti-Indonesian resistance in East Timor and in the diaspora as the primary linguistic marker of national identity and functioned as the language for international communication with Portugal and other countries. In local workshops and meetings organized by Australian Timorese and at which the first author participated in Melbourne in the 1990s, emphasis was most clearly placed on Portuguese as key to East Timorese identity, although the importance of Tetum was also acknowledged. Such a stance was subsequently confirmed by important discussions held in Melbourne with participation from across the diaspora as well as from East Timor only months before the referendum on independence in East Timor 1999 that ended Indonesian rule, where it was agreed that Portuguese would return as the sole official language, and would be the only language of education and officialdom, while Tetum would be accorded lower, national language status (Hajek 2000). However, in 2000-2001 as a result of tensions emanating from young adults in East Timor educated only in Indonesian and with little or no Portuguese but fluent in Tetum, a compromise was agreed during national consultations in East Timor: this allowed for constitutional co-officiality for both Portuguese and Tetum on independence in 2002. This choice coupled with the existing status accorded to Tetum because of its use in Timorese religious activities, as well as practical considerations (i.e. Tetum is by far the most widely understood language) have cemented Tetum's role as the primary linguistic identity marker in East Timor as well as in the non-Chinese Timorese diaspora in Australia and elsewhere. 
To see if national and individual identity might differ or align, participants were also asked to identify a language or languages considered to be an important part of their individual identity. Again Tetum clearly predominates $(n=21)$, with the most notable feature being an increase in the number of respondents who identified multiple languages. ${ }^{4}$

In the case of our Chinese Timorese respondents, all three identified Hakka as the linguistic marker of their East Timorese and individual identity- just as it is for the Chinese community in East Timor. This finding is not surprising - as already noted, a clear demarcation between Chinese and non-Chinese Timorese communities was well established in Portuguese Timor and continues to be evident today: there is relatively little socialization between these groups in Australia and for the most part, apart from some limited intermarriage, they tend to live very separate lives - a fact supported also by the fact the three Chinese Timorese respondents are not fluent in Tetum which is generally seen by other Timorese as strongly bonding the Timorese in Australia and elsewhere. The Chinese Timorese community in Australia (as in East Timor) has its own social organizations as well as social media outlets which operate mostly in Chinese (and therefore inaccessible to non-Chinese Timorese, albeit with some English used by younger members) and are very community-focussed, while the non-Chinese Timorese run their own activities and social media in Tetum, English and Portuguese, and as a result of a well-established history of public political activity in Australia in favour of East Timorese independence they also have strong links with the broader English-speaking Australian society (see also below).

\footnotetext{
${ }^{4}$ This is not a surprising outcome, since this question allowed for more than one response unlike the one specifically on East Timorese identity.
} 


\section{Language, social networks, media and transnational links}

Our respondents report maintaining contact in Australia with East Timorese, Australians and friends with a diverse immigrant background. Being in contact with other East Timorese, particularly family and friends, in person or online or meeting fellow East Timorese at events organised by East Timorese associations is not surprisingly common and helps to maintain East Timorese culture, including language and identity. In these settings, Tetum, English and Portuguese are typically used.

There is also a long history of contact in Australia between Portuguese-speaking Timorese and other Portuguese-speaking migrants (mainly from Portugal) who provided support to the East Timorese in their long and ultimately successful campaign in Australia against Indonesian occupation of the homeland. The small weekly Portuguese language press owned by the Portuguese community regularly included and continues to include news about East Timor, as well as information about the East Timorese in Australia, such as social events. Portuguese-speakers, across national distinctions, have also long shared religious activities organised by Portuguese-speaking Roman Catholic priests in Australia. All this said, however, such shared activity is more typical of the oldest wave of East Timorese who arrived in the 1970s and early 1980s as Portugueseeducated and acculturated refugees. Newer waves of Timorese, with less ability in Portuguese, are not as connected in the same way for obvious reasons.

The East Timorese is a relatively small immigrant community dispersed in multicultural cities such as Melbourne and Darwin, with no local media production. Instead, nearly all respondents $(\mathrm{n}=26)$ stated that they watch overseas TV programmes via the Internet or satellite television in any of the languages they speak. The three Hakka speakers answered they also watch programmes in Cantonese and Mandarin, while the other respondents answered they watch programmes in Indonesian, Portuguese and Tetum. 
The main way of meeting other Timorese beyond friends and family is through associations. The majority of respondents (25) stated they belong to formally organized East Timorese societies or cultural groups, including: the Darwin Timorese Community, Timor Ethnic Chinese Community of Victoria (TECC), East Timorese Students Association (ETSA) Melbourne, Melbourne East Timorese Activity Centre (METAC), or ETA Buffalo Soccer. Associations and events operate in different languages. Most non-Chinese East Timorese associations make use of Tetum and English in particular, as well as some Portuguese - at meetings, events and online. The willingness to use Tetum online, despite not having been educated in it, reflects both the symbolic importance of the language, but also mixed spoken-written nature of language on the internet, as well as the relative ease with which Tetum can be written without formal training, although spelling is often not consistent. As already noted, the Hakka-speaking Timorese join specifically East Timorese Chinese associations and online groups which make use, at least for written communication, mostly of Mandarin Chinese, with some use of English, but with no apparent use of Portuguese or Tetum.

There is very little evidence of online post-sharing on social media by the Chinese Timorese with other Timorese in Australia that would point to any significant interaction more broadly between the two groups. These rare shared posts typically involve interests common to younger Timorese, regardless of ethnic background. In these cases, they are specifically about football (cf. Cabral and Martin-Jones 2017) and are exclusively in English. They also serve to highlight the dominance of English in the Australian setting and its use as the only language that all young Timorese have in this country. 
Nineteen respondents answered they read magazines and newspapers in any one of the languages they speak, among the newspapers and magazines mentioned: Timor Post, STL, Tempo, Suara Timor, Lorosae Timor, Post Diario, all of which have some kind of internet presence and publish in multiple languages (Tetum primarily, but also Indonesian, Portuguese and sometimes English). Goglia and Afonso (2012) reported their respondents also access websites on news on East Timor and Indonesian music which has become popular in East Timor. It is worth noting that a small number of respondents ( $n=4$ and 5 respectively) indicated use specifically of Indonesian to access websites and TV programmes online, i.e. it has a very practical function.

Digital technologies also allow East Timorese in Australia to be connected with relatives and friends back home and in the diasporas. Seventeen respondents report belonging to East Timorese Facebook groups - based in Australia and overseas including in East Timor - on the internet. East Timorese who belong to Facebook groups are then part of a larger transnational community and exchange information on the country of origin, national and religious celebrations and more local events in the hosting countries.

\section{Final discussion and conclusion}

In this article we have discussed, amongst other things the complex linguistic repertoires of East Timorese resident in Australia, their language attitudes and practices as well as the linguistic basis of their perceived identities. Overall, we find a wide range of linguistic repertoires and patterns of language use - partly the result of different generational experiences of education through different mediums of instruction in East Timor and Australia (cf. also Hlavac 2012, 2015), but also partly because of linguistic diversity and distinctions across generations, space and ethnic communities (Chinese v 
non-Chinese) within both East Timor and Australia.

Our findings show that both English and Tetum receive highest scores as most widely known and spoken languages and with regard also to self-reported proficiency (see Figure 3). Not surprisingly, English is the new high language in the Australia context, whilst Tetum is the main East Timorese language in East Timor and Australia. The latter result is consistent with Tetum's recognised role as co-official language and national lingua franca in East Timor, as well as its association with the Roman Catholic Church in that country. With respect to identity, Tetum dominates in Australia, just as it does in Portugal and in East Timor itself. East Timor's long link to Portugal and today's co-official status for Portuguese in East Timor, in the absence of widespread proficiency and use in East Timor and in Australia, are not sufficient amongst our respondents, to make it as essential to Timorese identity as Tetum is.

In our study local East Timorese languages appear to occupy a limited space in respondents' linguistic repertoires and are not in general passed on to children, as Tetum takes hold of the community as its generally preferred in-group language. This pattern should be seen as mirroring two inter-related phenomena: (a) a shift under way towards Tetum from local languages in East Timor (Williams-van Klinken and Williams 2015), matched by (b) a similar shift to Tetum reported elsewhere in the East Timorese diaspora. Both are linked to the rise of a common East Timorese national identity most strongly associated with Tetum in East Timor and in the diaspora and the fact that for East Timorese traditionally divided amongst different local languages Tetum also functions as a lingua franca in East Timor and overseas. Goglia and Afonso (2012) found exactly the same situation in Portugal. The close-knit Fataluku community in Oxford with Fataluku as an essential identity marker is something of an exception to 
this general pattern (Zwack 2013), with less obvious status accorded to Tetum, although some movement in that direction is also evident.

However, signs of counter-shift to English at the cost of Tetum is also evident amongst younger Timorese born in Australia and elsewhere outside East Timor - again in line with patterns long observed amongst migrant communities in diasporic settings (e.g., Clyne and Kipp 2006). In addition, the three respondents who belong to the Hakka-speaking sub-group report good knowledge and use of Hakka instead of Tetum consistent with the strong identification between Hakka and the Chinese Timorese in East Timor, something that is clearly maintained in Australia. This difference in subgroup behaviour reminds us that immigrant communities from the same nation, no matter how small, are not homogeneous, but they may be made of sub-groups with strongly felt differences in ethnic and linguistic affiliation that persist in the diaspora. In the case of the East Timorese, the Hakka-speaking sub-group have a strong sense of group identity and a strong attachment to their own ethnic language which impacts on patterns of language knowledge, use and attitudes, which in turn restrict the degree and type of interaction - online and locally - with non-Chinese East Timorese in Australia and elsewhere.

If we return briefly to Portuguese, it is mostly only older respondents who report high proficiency in this language. These results are obviously different in the immigrant context in Portugal where Portuguese has the highest position in the repertoire being also the language of the host country and the former H-language until 1975 (and now reinstated formally since 2002) in East Timor. In Portugal both Portuguese and Tetum are passed on to children (Goglia and Afonso 2012), whilst in Australia where Portuguese has no wider status at all, the language has a much more limited role in East Timorese linguistic repertoires. 
As for Indonesian, it is known to those, mainly in the middle cohort in terms of age, who have been educated in the language in East Timor, but it has no emotional value, e.g. in terms of identity, and little functional value in practice in Australia - with its use most evident in accessing press and media online, and sometimes when communicating with friends. It certainly has little or no role in the family setting, which is the setting where use of Portuguese seems most evident (cf. Table 4).

Of course in practice despite a 'national' preference for Tetum amongst most of our respondents, as well as its link to national and personal identity, it is clear that the use of more than one language in the same context is common, whether it is with family members, in community activities or to access online media or social media. Available evidence also suggests however that this diversity will reduce over time in Australia as our youngest respondents already show signs of reduced multilingualism and greatest proficiency in English. 


\section{References}

Askland, Hedda Haugen. 2007. "Habitus, practice and agency of young East Timorese asylum seekers in Australia." The Asia Pacific Journal of Anthropology 8 (3): 235249.

Askland, Hedda Haugen. 2014. "Circulating stories: East Timorese in Australia and questions of post-independence identity.” Oceania 84 (2): 105-120.

Boon, Danielle, and Jeanne Kurvers. 2015. "Adult literacy education in Timor-Leste: Multi-layered multilingualism." The International Journal of Multilingualism 12 (2): $225-240$.

Cabral, Estêvão, and Marilyn Martin-Jones. 2017. "Moving North, navigating new work worlds, and re-mooring: Language and other semiotic resources in the migration trajectories of East Timorese in the UK." Entangled discourses edited by Caroline Kerfoot and Kenneth Hyltenstam, 89-108. Basingstoke: Routledge.

Clyne, Michael, and Sandra Kipp. 2006. Tiles in a multilingual mosaic: Macedonian Filipino and Somali in Melbourne. Canberra: Pacific Linguistics.

Costa-Pinto, Maya. 2012. “Transnationalism and relationships with 'home' among women in the East Timorese community in Melbourne." The Asia Pacific Journal of Anthropology 13 (3): 280-296.

Da Costa Cabral, Ildegrada. 2018. "From Dili to Dungannon: An ethnographic study of two multilingual migrant families from Timor-Leste.” International Journal of Multilingualism. doi: 10.1080/14790718.2018.1477289.

Goglia, Francesco. 2011. "Code-switching among Igbo-Nigerian immigrants in Padua (Italy).” In Postcolonial Linguistic Voices: identity choices and representations edited by Eric A. Anchimbe and Stephen A. Mforteh, 323-342. Berlin: Mouton de Gruyter.

Goglia, Francesco. 2015. "Multilingual immigrants and language maintenance: the case of the Igbo-Nigerian community in Padua." In Studi in onore di Alberto Mioni edited by Sara Gesuato and Maria Grazia Busà, 701-710. Padua: CLEUP.

Goglia, Francesco, and Susana Afonso. 2012. "Multilingualism and language maintenance in the East Timorese diaspora in Portugal." Ellipsis 10: 97-123.

Hajek, John. 2000. "Language planning and sociolinguistic environment in East Timor: Colonial practice and changing language ecologies." Current Issues in Language Planning 1 (3): 400-414. 
Hajek, John. 2002. "Language maintenance and survival in East Timor: All change now? Winners and losers." In Language Endangerment and Language Maintenance, edited by David Bradley and Maya Bradley, 182-202. London: Routledge.

Hajek, John. 2016. "Engaging with communities and languages in multilingual urban settings." In Doing research within communities, edited by Kerry Taylor-Leech and Donna Starks, 124-132. London and New York: Routledge.

Hlavac, Jim. 2012. "Continuing and shifting multilingualism in an émigré situation: language use and attitudes amongst Iraqi Chaldeans and Assyrians in Melbourne." International Journal of the Sociology of Languages 217: 195-218.

Hlavac, Jim. 2015. "Language maintenance and sociolinguistic continuity among two groups of first-generation speakers: Macedonians from Aegean Macedonia and the Republic of Macedonia." In Challenging the monolingual mindset, edited by John Hajek and Yvette Slaughter, 131-148. Clevedon: Multilingual Matters.

Migration Policy Institute (accessed on 4 July 2017) http://www.migrationpolicy.org/article/east-timor-old-migration-challenges-worldsnewest-country/

Musgrave, S. and J. Hajek. 2010. Sudanese languages in Australia: linguistic demography and language maintenance. In Y. Treis and R. de Busser (eds) Selected Papers from the 2009 Conference of the Australian Linguistic Society. Available at http://www.als.asn.au/proceedings/als2009/musgravehajek.pdf

Musgrave, Simon and John Hajek. 2013. "Minority language speakers as migrants: some preliminary observations on the Sudanese community in Melbourne." International Journal of Multilingualism, 10 (4): 394-410.

NSD/UNFPA. 2011. Population and Housing Census of Timor-Leste. Volume 3: Social and Economic Characteristics, Dili.

Pauwels, Anne. 2016. Language maintenance and shift. Cambridge: Cambridge University Press.

Rubino, Antonia. 2014. Trilingual Talk in Sicilian-Australian Migrant Families: Playing Out Identities Through Language Alternation. New York: Palgrave Macmillan.

Tabouret-Keller, Andrée. 1997. Language and identity. In Florian Coulmas (ed.), The handbook of sociolinguistics, 315-326. Oxford: Blackwell.

Taylor-Leech, Kerry. 2009. "The language situation in Timor-Leste.” Current Issues in Language Planning 10 (1): 1-68. 
Taylor-Leech, Kerry. (2012). "Language choice as an index of identity: linguistic landscape in Dili, Timor-Leste." International Journal of Multilingualism 9 (1): 1534.

Taylor-Leech, Kerry. (2013). “Timor-Leste: Multilingual education for all?” Ellipsis 10: 79-96.

Williams-Van Klinken, Catharina and John Hajek. 2018. "Language contact and functional expansion in Tetun Dili: the evolution of a new press register." Multilingua 37(6): 613-648 https://doi.org/10.1515/multi-2017-0109

Williams-van Klinken, Catharina and Robert Williams. 2015. Mapping the mother tongue in Timor Leste: Who spoke what where in 2010? Dili: Dili Institute of Technology.

Wise, Amanda. 2004. "Nation, transnation, diaspora: locating East Timorese longdistance nationalism." SOJOURN Journal of Social Issues in Southeast Asia 19 (2): 151-180.

Wise, Amanda. 2006. Exile and return among the East Timorese. Philadelphia: University of Pennsylvania Press.

Zwack, Camilla. 2013. Multilingualism and language maintenance in the Fataluku community of Oxford. MA diss., University of London. 
Table 1. Language knowledge of parents and respondents.

Table 2. First languages of partners and languages spoken by respondents with husband/wife/partner.

Table 3. What language(s) do you speak to your children and vice versa?

Table 4. Languages spoken with different interlocutors within the family and the community.

Figure 1. What is your first language?

Figure 2. Which of the following languages do you speak?

Figure 3. Please rate your ability in the language you speak.

Figure 4. What language(s) were used as a medium of instruction at primary school?

Figure 5. What language(s) were used as a medium of instruction at secondary school?

Picture 1. Facebook post - Timor Ethnic Chinese Community of Victoria

Picture 2. Facebook post - Timor Furak 


\begin{tabular}{|l|l|l|l|}
\hline Language knowledge & Father & Mother & Respondents \\
\hline monolingual & 7 & 8 & 0 \\
\hline multilingual & 22 & 21 & 29 \\
\hline Tetum & 19 & 15 & 23 \\
\hline Portuguese & 9 & 5 & 16 \\
\hline Indonesian & 2 & 1 & 17 \\
\hline Hakka & 3 & 3 & 3 \\
\hline Other Timorese & 14 & 17 & 7 \\
\hline English & 3 & 3 & 29 \\
\hline
\end{tabular}

Table 1: Language knowledge of parents and respondents 


\begin{tabular}{|l|l|l|}
\hline $\begin{array}{l}\text { First language(s) of and Language(s) spoken to } \\
\text { husband/wife/partner }\end{array}$ & $\begin{array}{l}\text { Partner's } \\
\text { L1(s) }\end{array}$ & $\begin{array}{l}\text { Lg(s) to } \\
\text { partner }\end{array}$ \\
\hline English & 3 & 5 \\
\hline English, Portuguese & & 1 \\
\hline Portuguese & 1 & \\
\hline Tetum & 8 & 7 \\
\hline Tetum, Makasae & & 1 \\
\hline Tetum, Portuguese, Indonesian & 2 & 1 \\
\hline Tetum, Indonesian, English & & 1 \\
\hline Tetum, Indonesian, Portuguese, English & & 1 \\
\hline Tetum, Indonesian, Fataluku & & \\
\hline Other Timorese language on own (Makasae, Baikenu) & 2 & \\
\hline Other Language & 1 & 13 \\
\hline No answer given & 13 & \\
\hline
\end{tabular}

Table 2: First languages of partners and languages spoken by respondents with husband/wife/partner 


\begin{tabular}{|l|l|l|}
\hline Language(s) spoken & $\begin{array}{l}\text { By parents to } \\
\text { children }\end{array}$ & By children to parents \\
\hline English & 5 & 7 \\
\hline English, Portuguese & 1 & 1 \\
\hline English, Tetum & 5 & 2 \\
\hline English, Tetum, Indonesian & 1 & 1 \\
\hline Portuguese & 1 & 1 \\
\hline Tetum & 2 & 3 \\
\hline Tetum, Makasae & 1 & 1 \\
\hline
\end{tabular}

Table 3: What language(s) do you speak to your children and vice versa? 


\begin{tabular}{|c|c|c|c|c|c|c|c|c|}
\hline \multicolumn{9}{|c|}{ What language(s) do you speak with these people? } \\
\hline Languages & 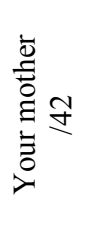 & 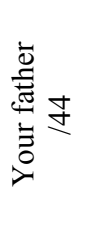 & 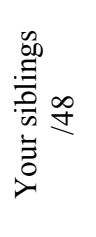 & $\begin{array}{l}\frac{n}{0} \\
\stackrel{0}{\Xi} 尺 \\
\vdots \\
0 \\
\vdots\end{array}$ & 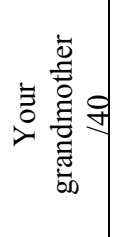 & 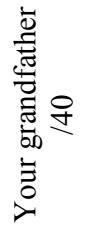 & 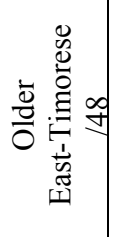 & 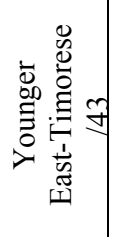 \\
\hline English & $\begin{array}{c}4 \\
(10 \%) \\
\end{array}$ & $\begin{array}{c}4 \\
(9 \%) \\
\end{array}$ & $\begin{array}{c}11 \\
(23 \%)\end{array}$ & $\begin{array}{l}23 \\
(33 \%)\end{array}$ & $\begin{array}{c}1 \\
(2 \%) \\
\end{array}$ & 0 & $\begin{array}{c}4 \\
(8 \%) \\
\end{array}$ & $\begin{array}{c}12 \\
(28 \%) \\
\end{array}$ \\
\hline Indonesian & $\begin{array}{c}1 \\
(2 \%)\end{array}$ & $\begin{array}{c}1 \\
(2 \%)\end{array}$ & $\begin{array}{c}3 \\
(6 \%) \\
\end{array}$ & $\begin{array}{c}12 \\
(17 \%)\end{array}$ & $\begin{array}{c}1 \\
(2 \%)\end{array}$ & $\begin{array}{c}1 \\
(2 \%)\end{array}$ & $\begin{array}{c}4 \\
(8 \%)\end{array}$ & $\begin{array}{c}5 \\
(12 \%)\end{array}$ \\
\hline Portuguese & $\begin{array}{c}5 \\
(12 \%)\end{array}$ & $\begin{array}{c}11 \\
(25 \%)\end{array}$ & $\begin{array}{c}8 \\
(17 \%)\end{array}$ & $\begin{array}{c}9 \\
(13 \%)\end{array}$ & $\begin{array}{c}4 \\
(10 \%)\end{array}$ & $\begin{array}{c}5 \\
(12 \%)\end{array}$ & $\begin{array}{c}5 \\
(10 \%)\end{array}$ & $\begin{array}{c}3 \\
(7 \%)\end{array}$ \\
\hline Tetum & $\begin{array}{c}22 \\
(52 \%)\end{array}$ & $\begin{array}{c}18 \\
(41 \%)\end{array}$ & $\begin{array}{c}20 \\
(42 \%)\end{array}$ & $\begin{array}{c}22 \\
(31 \%)\end{array}$ & $\begin{array}{c}19 \\
(47 \%) \\
\end{array}$ & $\begin{array}{c}15 \\
(37 \%)\end{array}$ & $\begin{array}{c}21 \\
(44 \%)\end{array}$ & $\begin{array}{c}19 \\
(44 \%)\end{array}$ \\
\hline Hakka & $\begin{array}{c}3 \\
(7 \%) \\
\end{array}$ & $\begin{array}{c}3 \\
(7 \%)\end{array}$ & $\begin{array}{c}1 \\
(2 \%)\end{array}$ & $\begin{array}{c}0 \\
(0 \%)\end{array}$ & $\begin{array}{c}3 \\
(7 \%)\end{array}$ & $\begin{array}{c}2 \\
(5 \%)\end{array}$ & $\begin{array}{c}2 \\
(4 \%) \\
\end{array}$ & $\begin{array}{c}3 \\
(7 \%) \\
\end{array}$ \\
\hline Other Timorese Languages & $\begin{array}{c}5 \\
(12 \%) \\
\end{array}$ & $\begin{array}{c}6 \\
(14 \%) \\
\end{array}$ & $\begin{array}{c}2 \\
(4 \%) \\
\end{array}$ & $\begin{array}{c}2 \\
(3 \%) \\
\end{array}$ & $\begin{array}{c}7 \\
(17 \%) \\
\end{array}$ & $\begin{array}{c}9 \\
(22 \%) \\
\end{array}$ & $\begin{array}{c}5 \\
(10 \%) \\
\end{array}$ & $\begin{array}{c}1 \\
(2 \%) \\
\end{array}$ \\
\hline Other Languages & $\begin{array}{c}1 \\
(2 \%)\end{array}$ & 0 & 0 & $\begin{array}{c}1 \\
(1 \%)\end{array}$ & 0 & 0 & 0 & 0 \\
\hline Not Applicable & $\begin{array}{c}1 \\
(2 \%) \\
\end{array}$ & $\begin{array}{c}1 \\
(2 \%) \\
\end{array}$ & $\begin{array}{c}3 \\
(6 \%) \\
\end{array}$ & $\begin{array}{c}1 \\
(1 \%)\end{array}$ & $\begin{array}{c}5 \\
(12 \%) \\
\end{array}$ & $\begin{array}{c}8 \\
(20 \%) \\
\end{array}$ & $\begin{array}{c}3 \\
(6 \%) \\
\end{array}$ & $\begin{array}{c}5 \\
(12 \%) \\
\end{array}$ \\
\hline
\end{tabular}

Table 4: Languages spoken with different interlocutors within the family and the community, based on number of mentions of a language for specific interlocutor(s) 


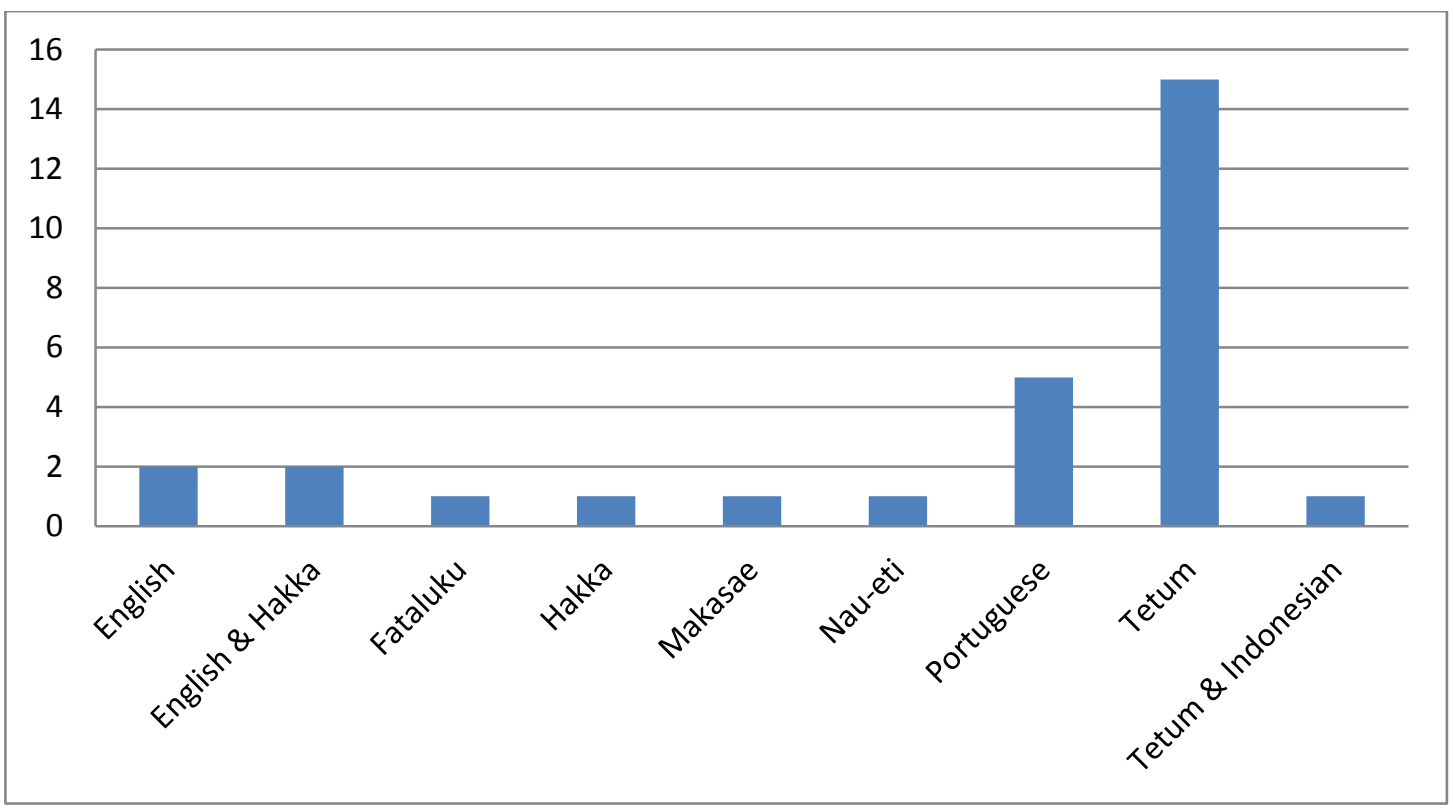

Figure 1. What is your first language? 


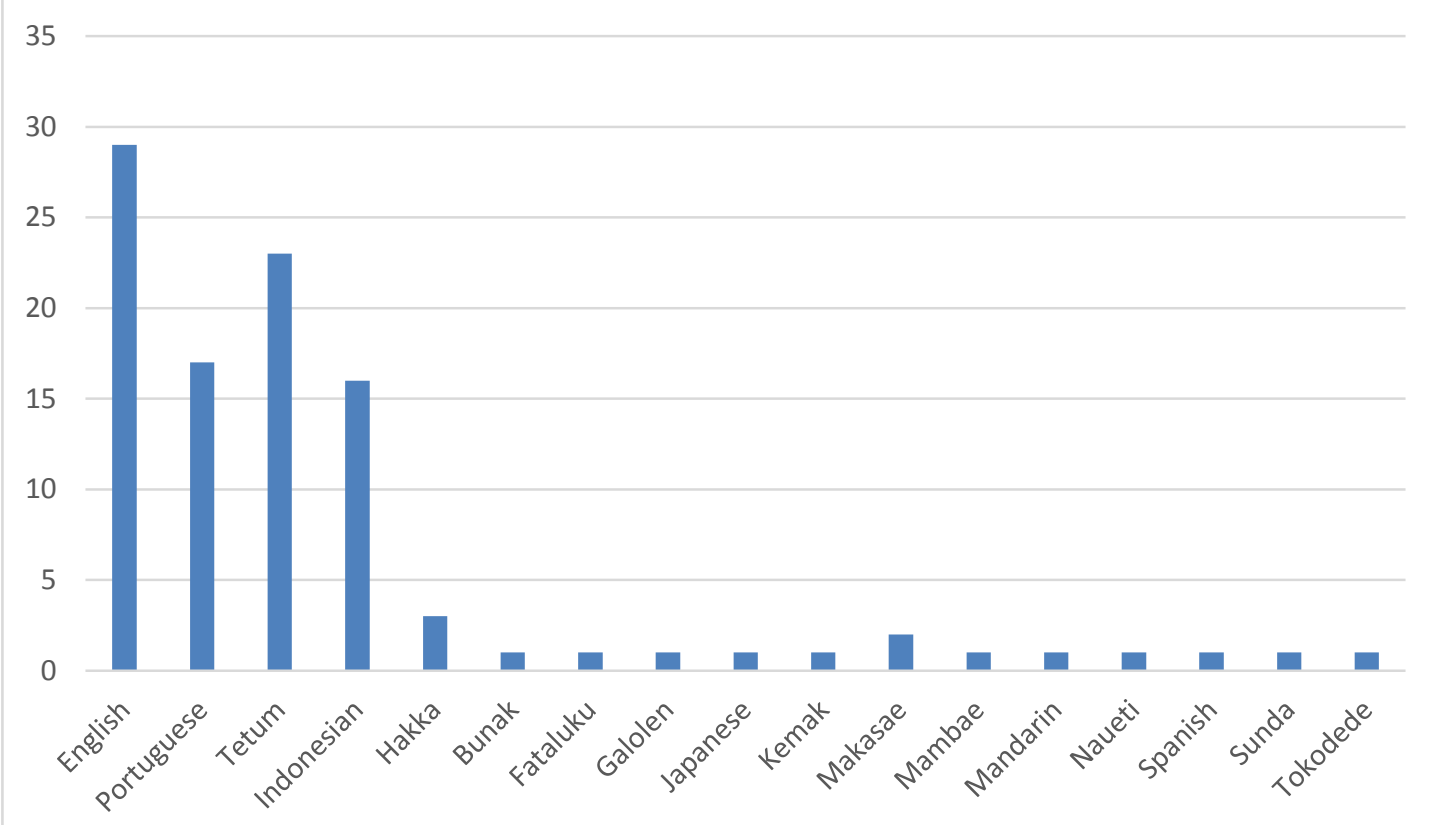

Figure 2. Which of the following languages do you speak? 


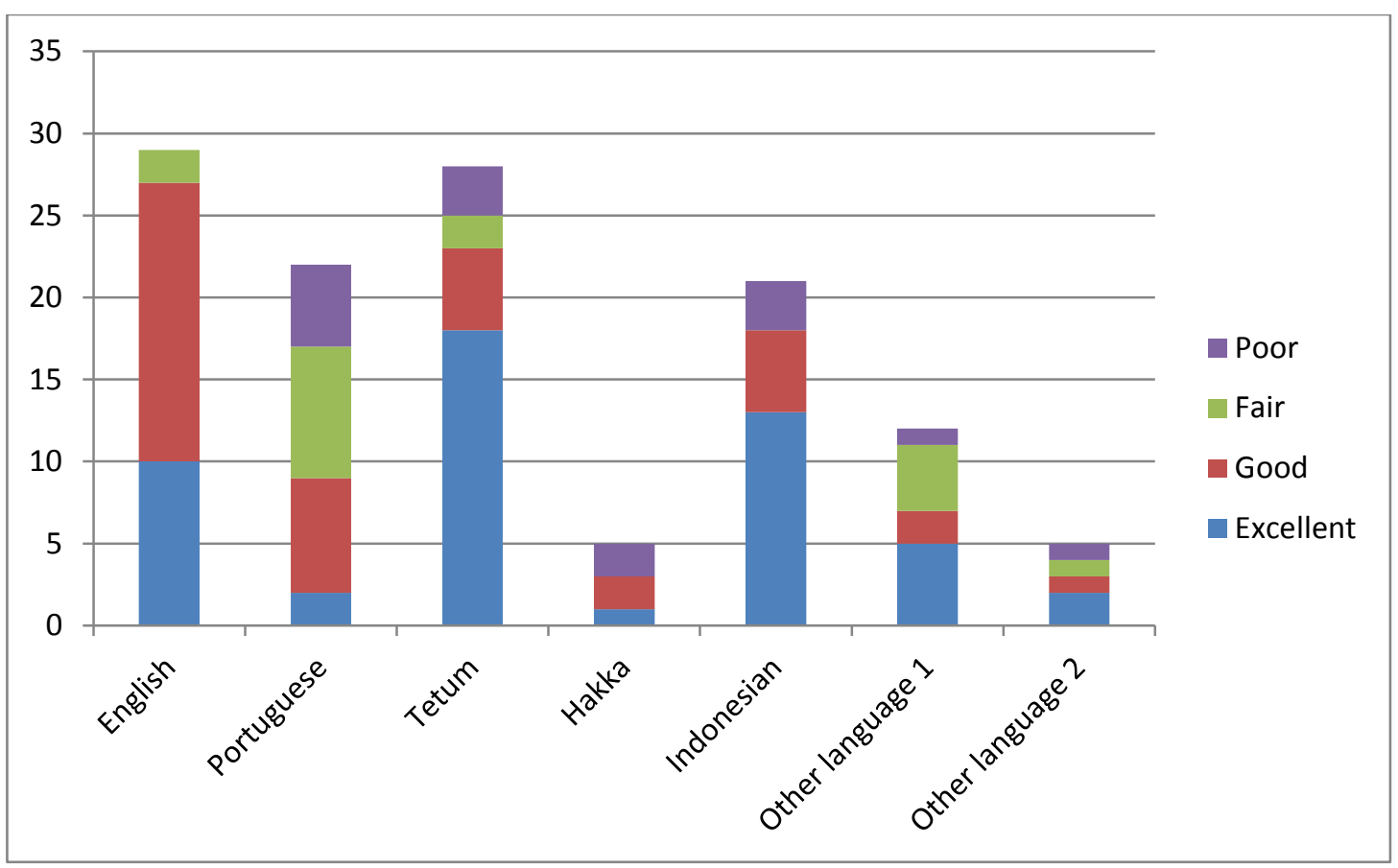

Figure 3. Please rate your ability in the language you speak. 


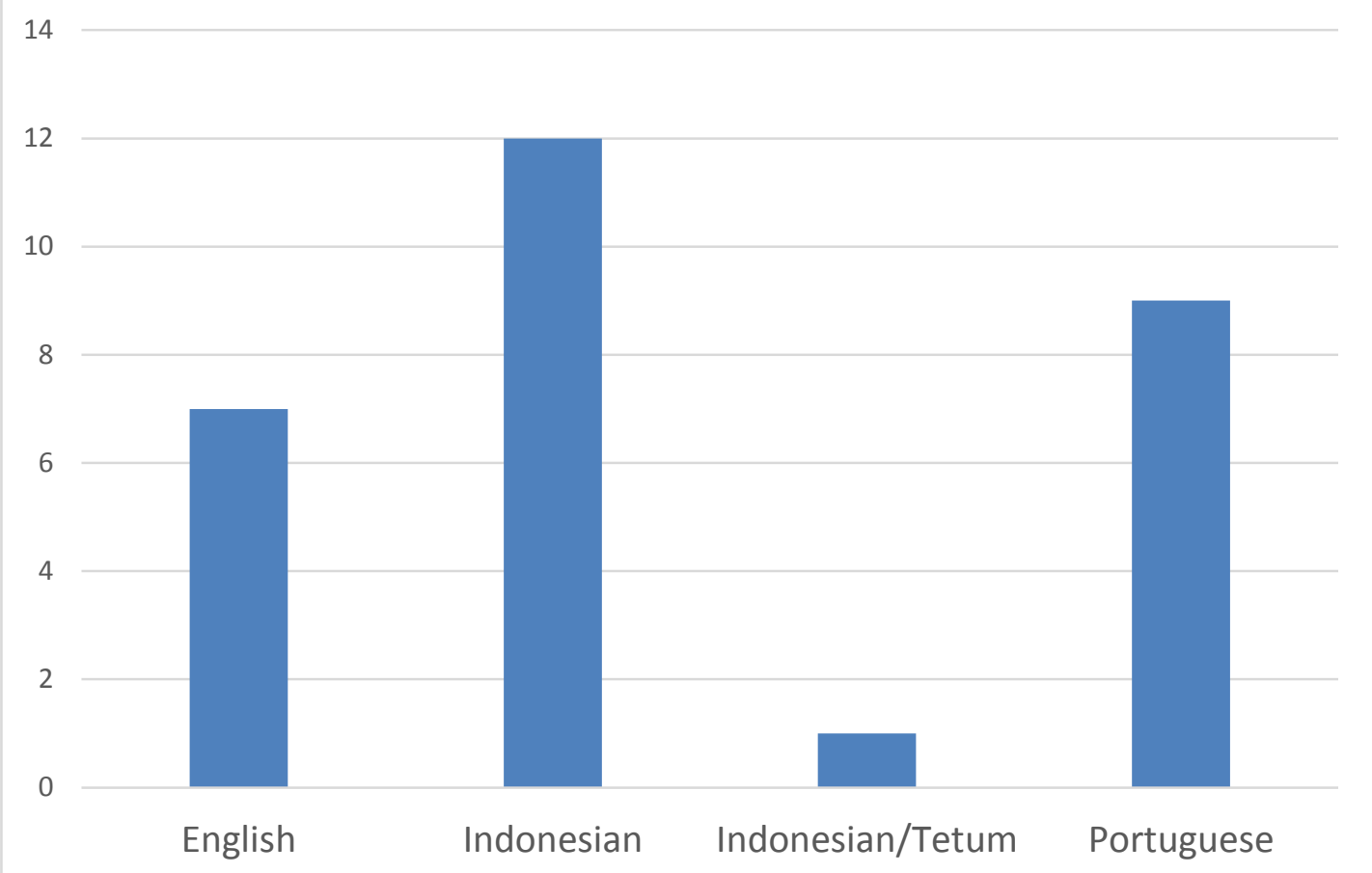

Figure 4. What language(s) were used as a medium of instruction at primary school? 


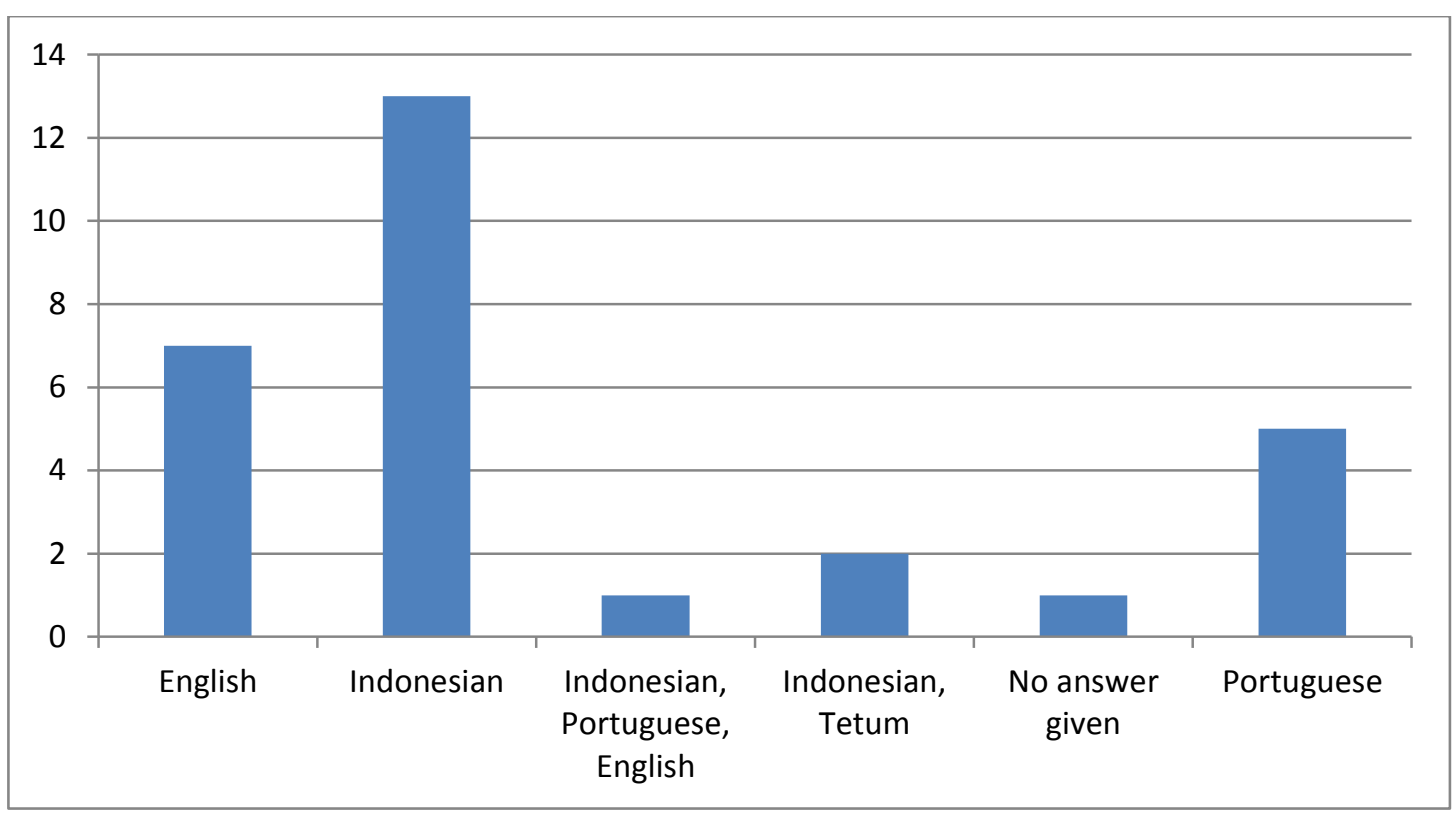

Figure 5. What language(s) were used as a medium of instruction at secondary school? 


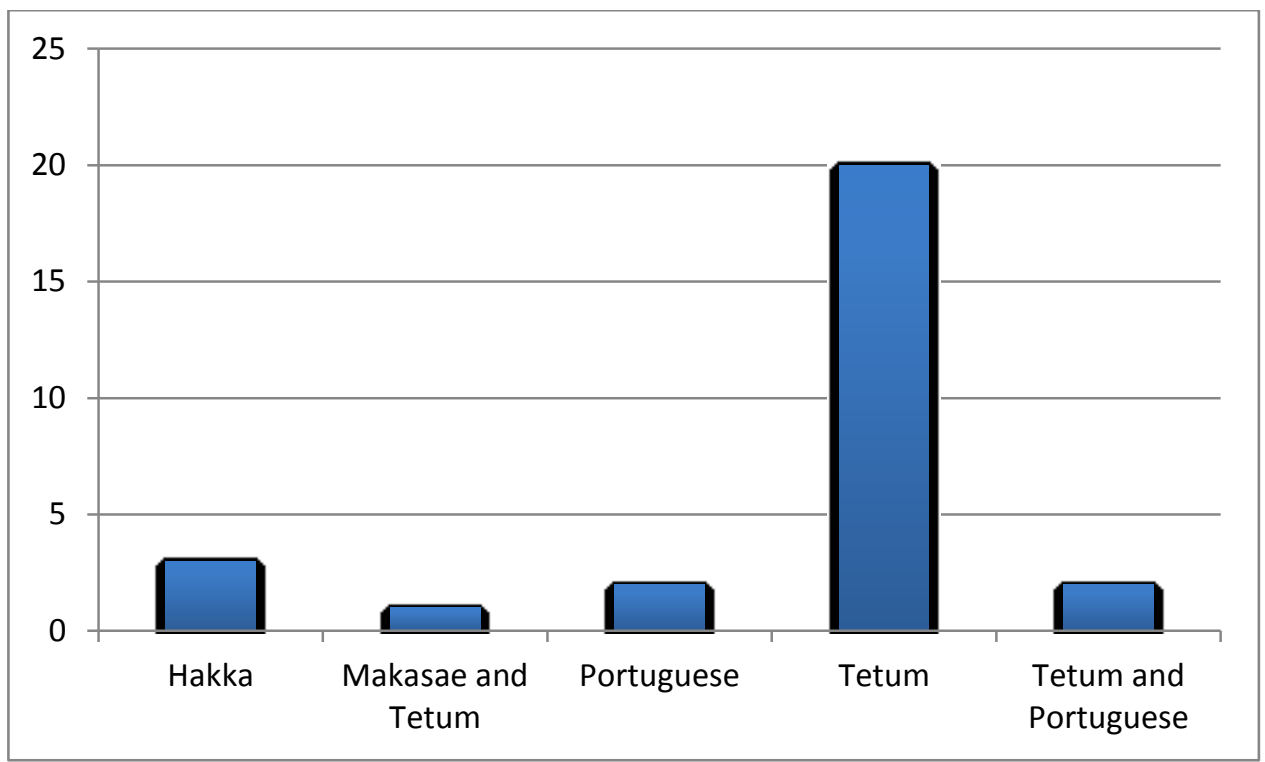

Figure 6. What language among those you speak represents best your East Timorese identity? 
